\title{
Hermeneutics: Polity, Politics, and Political Theory in Gadamer's Philosophical Hermeneutics
}

\begin{abstract}
This article discusses the significance of Hans-Georg Gadamer's philosophical hermeneutics for political science and political theory. As a critical observer of contemporary culture, dominated, as it is, by scientific, bureaucratic, and technological conceptions of the public sphere, Gadamer highlights the rootedness of human interaction and praxis in dialogical exchange. Consequently, according to him, the genuine dimension of politics should be conceived of from the perspective of its participants and not from the point of view of a neutral observer. Building on this methodological assumption, the article reconstructs, first, the analysis of practical knowledge as presented in the early writings of Gadamer. A second step leads to the hermeneutical conception of practical knowledge, which Gadamer articulated through a reinterpretation of Aristotle's 'phronesis'. Most centrally, it discusses the consequences of this idea of practical knowledge for an adequate account of understanding. A third section focuses on the late Gadamer's reflection on political deliberation as an essentially dialogical activity that opens the possibility to elude technological and bureaucratic manipulation.
\end{abstract}

Keywords: Hans-Georg Gadamer, political theory, polity, politics, hermeneutics

Hans-Georg Gadamer is the outstanding figure of philosophical hermeneutics. Despite the fact that he never directly addressed questions concerning the methodology of political science, Gadamer's philosophical hermeneutics is an important interlocutor for everyone seeking orientation in the field of political thought and political theory. Attentive inquiries into the normative dimensions of human experience lead the hermeneutician to a circumspect account of the interrelation between ethics, moral philosophy, epistemology, and methodology. In general, philosophical hermeneutics is highly context-sensitive. Consequently science cannot be, at least in the hermeneutical perspective, conceived of as pure theory, independent of a concrete historical framework and specific contextual conditions. Gadamer believes that there is no a-historical essence of rationality and, accordingly, no a-historical essence of science. Historical reflection and contextualist awareness make it possible to recognize the signature of the present 
era, they enable the hermeneutician to recognize the peculiar constellation caused by the increasing dependency of scientific research on specific political and economic interests while at the same time political decision-making relays more and more on scientific research and economical constraints.

Gadamer is deeply influenced by Martin Heidegger. For Heidegger the sciences are instruments giving explanations, making possible the exploitation of nature by technology, and delivering prognostics that will, according to official rhetoric, allow bureaucratic societies to master the future. For Heidegger these are significant contributions of the sciences that give the contemporary world its characteristic shape. But these achievements are not forms of 'thinking'. There is a crass dichotomy of science and philosophy in Heidegger, and this cleavage is certainly not without problems. Gadamer, beginning his own work in the shadow of Heidegger, softens some of the harsh pronouncements of his master and thereby eludes some impasses. But what he has in common with Heidegger during all of his writings is the belief that western culture is dominated by a restricted and highly problematic conception of science and scientific method.

The political sphere, according to Gadamer, has to be conceived of as an open realm that is not controlled by scientific protocols, but rather is to be understood properly only from the point of view of the participants. This point of view is not to be identified with the position of an isolated, rational decision-maker calculating incessantly the maximal utility of his behavior. For Gadamer this is not the exemplary figure one has to look at in order to understand human agency and human communities. What counts here is the fact that every individual is a member of a language community who is always involved in communicative and dialogical exchanges with others. To grasp the impact of this idea, it may be useful to single out some of the most important sources of Gadamer's thinking about praxis, polity and political science. I shall start with Gadamer's, often neglected, early writings. Here Gadamer is concerned with ethical problems and the problem of ethics as a theoretical enterprise. I shall briefly discuss his Habilitationsschrift Platos dialektische Ethik (1929, published in 1931) (Gadamer, 19861, pp. 3-163) and his seminal paper 'Praktisches Wissen' (1930) (Gadamer, 1986m) (I.). Then I shall move on to Gadamer's Wahrheit und Methode (1986p), published in 1960. This book undertakes a revaluation of practical knowledge that is linked to the key idea of hermeneutics, the concept of understanding. It is only on the basis of this hermeneutical conception of understanding that it is possible to get access to Gadamer's ideas on community, political praxis and scientific knowledge (II). In the last section I shall present the main arguments on politics, science, and political theory in the papers of the late Gadamer (III.). 


\section{The good, ethics and ethical theory}

During the winter term 1928 Gadamer presented his habilitation thesis (Habilitationsschrift) at the University of Marburg: Platos dialektische Ethik (Plato's dialectical ethics) (Gadamer, 19861). The text presents an assessment of the much debated relation between Plato's moral philosophy and Aristotle's ethics. Gadamer proposes a reading of Plato's Philebos in the light of Aristotle's ethics. During the first quarter of the $20^{\text {th }}$ century, philological work on Plato and Aristotle was largely dominated by studies trying to establish a chronological order of the texts and explaining the evolution of Plato's and Aristotle's philosophies. The focus was on the history of ideas and an encompassing historicist reconstruction of Greek philosophy. Traces of this background are still visible in Gadamer's approach but much more important is the philosophical influence of Heidegger. Heidegger's lectures on ancient Greek philosophy in Marburg impressed Gadamer profoundly and he explicitly claims his thesis to follow the way Heidegger is leading (Gadamer, 1986e, p. 18). Heidegger's analyses of Plato and Aristotle can be understood as reactions against the then influential approach of neo-Kantian philosophers. Paul Natorp and others had given interpretations in which Plato appeared as a systematic thinker formulating an encompassing metaphysics on the basis of the doctrine of ideas (Natorp, 1903). ${ }^{1}$ Gadamer, as well as many others, raised objections against this conception of Plato as a system builder. More specifically, he claimed that Plato never formulated a philosophical ethics in the sense of a theoretical discipline. Plato should be understood as a Socratic thinker, the Socrates of the Platonic dialogues expressing Plato's own philosophical beliefs (Gadamer, 1986e, p. 6). ${ }^{2}$ Plato's philosophy, accordingly, is dialectical thanks to its medium, Socratic dialogue. If one follows this line of argument it becomes plausible to think that philosophy is not a corpus of theorems and propositions one can learn by heart and take home. ${ }^{3}$ The Socratic element of Plato's dialectic is constituted by the fact that striving for knowledge never gets to an end, the aspiration to last justifications is never fulfilled and every thinker is in need of an interlocutor testing the soundness of arguments and questioning the validity of given proofs. Platonic philosophizing is a process not a product. These ideas concerning the philosophical relevance of conversation and dialogue are the sources for Gadamer's later elaborations on the 'logic of question and answer' and dialogical language as a necessary medium of hermeneutic un-

Natorp had been supervisor of Gadamer's dissertation Das Wesen der Lust nach den platonischen Dialogen (1922); cf. Gadamer, 1986k, pp. 375-380.

Gadamer explicitly recognizes the unity of dialogue and dialectic; cf. Gadamer, 1986e, p. 14.

The interpretation of Plato as representative of a system oriented philosophy was of course not an invention of neo-Kantianism. A good example of $18^{\text {th }}$ century Plato-scholarship reducing the Platonic dialogues to a dogmatic canon of 32 propositions is the article 'Platonische Philosophie' (Zedler, 1961). 
derstanding. ${ }^{4}$ Gadamer argues that Platonic dialectic is essentially dialogical. The dialogical moment is necessary because the isolated thinker is not able to go beyond his own horizon without an interlocutor who challenges and criticizes his beliefs (Gadamer, 1986e, pp. 6-7).

Human beings have no complete epistemic mastery of themselves and their lives. They are trying to get a better understanding of their own situation. Human existence itself is this search. There is never a final closure, a definite and last answer to be reached. However, it would be too much of heideggerian inspiration to make Plato the herald of human finitude. Gadamer rightly stresses the fact that Plato never recants the ideal of pure theory. Plato clings to this ideal throughout all of his writings. Human life and praxis come into view only in the light of the ideal of pure theory.

Whereas in Plato the quest for knowledge is oriented by the ideal of pure theory and while the experience of human life excludes a fulfillment of this quest, as the dialectics of Socratic dialogue clearly shows, Aristotle is the real founder of ethics as a theoretical discipline. Aristotle is able to do this by abandoning Plato's ideal of pure theory. Of course, for Aristotle the concept of ideal, perfectly stable, changeless entities and eternally valid propositions is still important. But this concerns primarily theoretical philosophy. The world of human action and communication becomes in itself valuable to philosophical thought. The fact that social and political reality cannot be understood as exemplifications of perfect Platonic ideas is accepted and becomes an invitation to think the domain of ethics and politics in its own terms. Aristotle is the first philosopher to conceive of the human good in itself, he implements a differentiation of theoretical philosophy and practical philosophy. Knowledge concerning the human good has not the same structure as pure theoretical knowledge.

In 1930 Gadamer wrote a paper 'Praktisches Wissen' ('Practical knowledge') destined to be published in a Festschrift dedicated to the famous philologist Paul Friedländer (Gadamer, 1986m, pp. 230-248; 1986j, pp. 403-405). The book never got published and it was only in 1985 when the article finally appeared into print. This early article sums up Gadamer's thinking on Plato and Aristotle and contains important conceptions he shall come back to in Wahrheit und Methode (Truth and Method) (Gadamer, 1986p). He starts with a brief methodological remark expressing a proviso concerning the possibility of a contemporary reader to understand ancient thought on ethical problems. He points out to the danger to distort and deform the ideas of the ancient thinkers by reading them on the basis of Christian conceptions constitutive to modern western culture. Gadamer does not go further into this problem which should later become of paramount importance in his philosophical hermeneutics when he discusses the historicality of understanding and the hermeneutic circle (Gadamer, 1986c, pp. 270-312). 
Aristotle accomplishes a fundamental transformation of philosophical discourse by elaborating a distinction of different modes of knowledge. ${ }^{5}$ Theoretical knowledge in the Platonic tradition is true justified belief about invariable facts and eternal structures. A profound tension in Plato is caused when the idea of the good must be related to the sphere of human life and human action. The facts, norms and structures of human life are not invariable like mathematical propositions. The Aristotelian answer to the questions 'Is it possible to know the human good in the same manner as one knows a deductive proof to be valid?' is 'No'. A flaw in the Platonist account becomes visible: even if the Platonist knew the idea of the good this knowledge wouldn't enable him by itself to life a good life. What does it mean, then, for a human being to know the good? Aristotle proposes a solution to the problem by making a distinction between several forms of knowledge:

(i) Mathematics and logic are paradigmatic disciplines of theoretical knowledge $($ episteme $)$. Deductive validity and demonstrative proof are characteristic of theoretical knowledge.

(ii) Technique (technē) is knowledge about the production of artifacts. This is to a large extent identical with instrumental knowledge, i.e. knowledge concerning the adequate means to attain given ends.

(iii) Practical knowledge or prudence (phronesis) concerns the good life of humans as social and political beings

(iv) Wisdom (sophia) and (v) intuitive reason (nous) are not relevant for the purposes of ethics and practical philosophy (NE 1139b15-17).

Aristotle clearly rejects the idea of a science enabling humans to perform a calculus of the good life. This does not imply, however, that Aristotle is renouncing the idea that there is knowledge about the good. Gadamer comments on the notion of practical knowledge by stressing the difference between what is general, universal and what is singular, individual.

In order to understand the idea of Aristotle adequately it is useful to observe a difference separating Aristotle's general approach to action and modern ideas about morality. Practical knowledge or prudence concerns what is good for a human life. This conception of the human good and the prudent action must not be identified with the modern idea of what is good in the sense of morality. The human good has not only a larger meaning for Aristotle than the moral good of modernity, it is different in structure. Aristotle holds that all human beings performing actions are taking care of themselves and trying to achieve their

For a detailed interpretation of Aristotle's conceptions cf. Aubenque, 1986; Wolf, 2002. 
own best. Sometimes humans may go wrong, at other times they may succeed in achieving their good. However, it is impossible to life the live of a human being without taking care of oneself and deliberating about one's own projects, desires and decisions. So, ethics is rooted in the basic structure of human existence and action. Living a good life does not depend exclusively on rational thought but without rational deliberation and decision there is no possibility that a human life could flourish and prove a person's excellence. In order that the lives of humans be good lives it is necessary, according to Aristotle, that rationality should guide the deliberations and actions in an appropriate way. This seems rather obvious under the presupposition that humans are essentially rational animals. But what exactly does it mean to say that the actions of a person are guided in an appropriate way by prudence or practical reason? What is of prime importance in contrast to Plato is the idea that practical rationality cannot be identified with theoretical reasoning. Every human being lives his own life. No one is living his life primarily as an example of a human life in general. Human existence is individualistic and it is a brute singular fact that stands not at the disposition of the individual ('Unverfügbarkeit'). I am in this world and therefore I have to see what I can do with this given fact. There is no science, no technique that can teach me how to life and lead my own life. And there is no scientific answer to the question 'How can I succeed in living a good life?'. Gadamer characterizes practical knowledge in opposing it to theoretical knowledge that can be defined as knowledge at distance. Practical knowledge is not knowledge at distance (Gadamer, 1986e, p. 242). It is neither separable from the character of the individual nor from the concrete context of the individual's deliberation.

In the sixth book of his Nicomachean ethics Aristotle carefully underlines this peculiarity of practical knowledge. Practical knowledge is personal and context-related. Therefore Aristotle does not give a general and strict definition of practical knowledge. Instead he is referring to the single individual whose actions prove that she is prudent in human affairs and knows how to realize her good (NE 1140a24-28).

Practical knowledge is concrete, individualized, and contextualized. It cannot be generalized since it is equivalent to the way the prudent person is taking care of her own life. It is obvious, however, that Aristotle's remarks on practical knowledge are not completely clear and neatly arranged. One of the often discussed points is the problem whether practical knowledge is knowledge concerning the appropriate means to a specific end or if it is in addition to the knowledge about means also knowledge concerning appropriate ends of actions. If practical knowledge were exclusively knowledge about means, wouldn't practical knowledge and technical knowledge be identical or indistinguishable given the fact that both forms of knowledge were about means of action? It is rather obvious that if practical knowledge would be solely about the means and not at all about ends of action, the distinction between practical knowledge (phronesis, 
prudence) and technique would collapse. The concept of technical knowledge does not imply the distinctions one needs in order to speak about a good human life. The knowledge that a certain action secures a specific result does not enable one to tell whether the action would contribute to a good life. In order to know how to kill people in the most effective way one needs technical knowledge. The corresponding capacity is called skill or cleverness. Cleverness as such is ethically neutral. Clever people can act in a prudent or in an imprudent manner. Aristotle denies that cleverness and prudence are identical. The knowledge that enables people to live a good life implies more than pure cleverness. Perhaps one could say that prudence implies cleverness, if used at all, to be used in the right perspective. Technical knowledge may be an element within practical knowledge but it cannot be identified with it (NE 1144a23-30).

Gadamer pays special attention to the fact that in the Nicomachean Ethics Aristotle specifies practical knowledge as an attitude ('hexis') of the individual. This conception of knowledge as an attitude in the Nicomachean Ethics differs from what Aristotle says in his Metaphysics where knowledge is a capacity ('dynamis'). An attitude is not a capacity but an orientation. Practical knowledge is an attitude that is characterized by the fact that the individual deliberates properly about the good. This implies that rules are not automatically followed but interpreted and concretized in view of the peculiar context of action.

Furthermore, Aristotle thinks the human good to be the good life as a totality or a unity. This is of paramount importance. The human good cannot be identified with a concrete end of a singular decision. The focus on the good life as a whole (NE 1140a28) constitutes a decisive difference that separates prudence from technique. The end secured by practical knowledge is not a product as the end of a technical discipline, but the whole of a human life formed by the rational deliberation of the individual. To be sure practical knowledge concerns first of all individual matters but its scope is extended beyond the realm of intimate relations to partners, children, parents and friends into the whole sphere of the political community. The well-being of the individual, the family and the polity are altogether taken into account in practical knowledge: the legislature and the executive are forms of practical knowledge (NE 1141b23-1142a10). Gadamer underlines the fact that Aristotle's philosophy of praxis forms a bipartite unity comprehending ethics and politics. And he recognizes explicitly that, at least since the $19^{\text {th }}$ century, this unity has broken down. ${ }^{6}$ The question arises whether contemporary political thinking can still profit from Aristotle's ideas. The con-

6 Gadamer addresses this problem in his paper 'Aristoteles und die imperativische Ethik' first published in 1989, cf. 1986a, pp. 381-395. M. Schofield equally points to the change the concept of politics underwent. He not only hints at the junction of politics and ethics but gives the political dimension a priority: "For us, ethics and politics signify two distinct, if overlapping, spheres. For Aristotle, there is just one sphere - politics - conceived in ethical terms." (Schofield, 2006, p. 309). 
clusion of Gadamer's article 'Praktisches Wissen' seems to be doubtful on this point. In a Hegelian perspective on the history of philosophy Gadamer situates Aristotle's philosophy of praxis in the past world of the Greek polis. He gives no indication that he thinks it appropriate to validate Aristotle's conception for the contemporary world. As we shall see in the following paragraph this historicist farewell to Aristotle is not Gadamer's last word, to the contrary, he shall become confident that Aristotelian 'phronēsis' is still relevant for us.

\section{Philosophical hermeneutics, understanding, and practical knowledge}

Gadamer's Wahrheit und Methode (1960) (Gadamer, 1986p) is a critique of the idea that truth is exclusively attained by scientific methodology: a problematic and distorted conception of truth relying exclusively on scientific knowledge dominates contemporary western culture (Gadamer, 1986p, 1986d, 1986o, 1986n). Some readers remarked the title Wahrheit und Methode (Truth and Meth$o d)$ to be somewhat misleading because it seemed to refer to a synthesis of truth and method as complementing one another. This, however, would be just the contrary of Gadamer's intentions. The original intention would be much more directly expressed by a title like Either truth or method (Turk, 1982, pp. 120-150). Even if the crass disjunction seems to be of a more Heideggerian than Gadamerian spirit, it gives a hint at Gadamer's general perspective. Gadamer takes a highly critical look at the idea that there is one single methodology that leads towards knowledge, namely the methodology of the exact sciences. His diagnosis shows that the $20^{\text {th }}$ century is obsessed with epistemology and methodology. He develops this critique by studying the history of the so-called 'Geisteswissenschaften' (history, philology, cultural studies). He points at frequent misunderstandings of scientific disciplines caused by the idea that epistemic value can be measured exclusively according to the standards of the natural sciences. In its historical parts Wahrheit und Methode shows how the exact sciences overwhelm, since the end of the $18^{\text {th }}$ century, the human and social sciences with their achievements and impose their methodological strategies on them. Against this tendency, philosophical hermeneutics tries to revive modes of knowledge that are of utmost importance especially for the social and cultural sciences. The interpretation of texts is the paradigm that Gadamer's refers to in order to show that there is knowledge in the humanities that cannot be completely reduced to methodologically standardized procedures. Gadamer wants to demonstrate firstly that to follow rules of interpretation is not equivalent to apply strictly scientific methods and, secondly that obedience to given rules is not sufficient to guarantee interpretative success (Grondin, 1991; Dutt, 1993; Teichert, 2004, cols 1339-1344). 
It is in this context that Gadamer takes up Aristotle's conception of practical knowledge and uses it as paradigm of hermeneutical knowledge. Whereas 'Praktisches Wissen' presented Aristotle in a Hegelian gesture as a great but dated epoch in the history of ideas, thirty years later Gadamer proceeds towards a systematic revalidation of Aristotelian 'phronēsis'. His interest is not primarily directed at ethical problems but at the peculiar structure of practical reasoning. The paragraph devoted to this new reading of Aristotle is part of the crucial second chapter in the second part of Wahrheit und Methode. In order to grasp Gadamer's strategy it is indispensable to look at least briefly to the transformations of the traditional conceptions of understanding and interpretation.

\section{II.1. Understanding and interpretation}

A widespread conception defines understanding as the successful interpretation of a speaker's message by a hearer. Sometimes success is attained via the correct ascription of meaning based on a grasp of the utterance's truth conditions. If Julie says to John "La fênetre est ouverte", John understands the sentence if he knows under which circumstances the sentence is true. "La fênetre est ouverte" is true if the window is open. Assuming John never learned French it would only be a lucky guess if he should think "Julie says 'The window is open". If John has just learned his first lesson of French and thinks "La fênetre est ouverte" meant "Dinner is excellent tonight" he does not assign the correct meaning to the words, and consequently misunderstands the message. If John makes some progress in his language acquisition he will come to understand "La fênetre est ouverte" properly. Understanding under this approach is bivalent, successful or unsuccessful depending on the correctness of the interpretation of the message. Of course understanding implies much more than that. The pragmatic dimension or the aspect analyzed by speech act theories is crucial. In uttering " $\mathrm{La}$ fênetre est ouverte" Julie might express the wish that John should close the window or she might tell John that somebody had entered the room during their absence etc. In fact, philosophical hermeneutics has much more affinities to pragmatics and contextualist approaches than to truth-conditional semantics because of its context-sensitivity. However, philosophical hermeneutics, in sum, adopts a completely different perspective than those of semantics or pragmatics. Whereas understanding is generally conceived as a mental disposition or a mental state resulting from the correct determination of the meaning, the focus of philosophical hermeneutics is different. Philosophical hermeneutics tries neither to reduce meaning to truth nor truth to meaning but is convinced that understanding propositional content is not sufficient in order to account for human understanding in general. In order to determine the meaning of a sentence there must already be an orientation towards meaning that cannot in itself be 
a linguistic competence. Heidegger's existential or fundamental ontological conception of understanding refers to a basic opening of sense and meaning that is not to be identified with linguistic or propositional understanding. Existential, fundamental ontological understanding is a pre-lingual situatedness of human experience in general. The basic fact of human existence is being in the world, a world that is always already meaningful. Sense and meaning are already open to the experiencing individual at a basic behavioral level. Lingual meanings are dependent on this primary structure that is labeled as 'fundamental ontology'. This term is used Heidegger in Sein und Zeit and should not be confounded with a foundation of ontology in the meaning commonly used in philosophy. Whereas traditional ontology enquired into the (kinds of) entities that exist, Heidegger examines the foundations and presuppositions of such traditional forms of thinking. For that reason he draws a distinction between Being ('Sein') and entities ('Seiendes'). The fundamental question of philosophy is the question of the sense of Being ('Sinn von Sein'). According to Heidegger the only possibility to proceed is to analyze the mode of being that comes to manifest itself in human existence. He rejects the traditional vocabulary ('Mensch', 'subject', 'person', 'Ego') and uses throughout Sein und Zeit the term 'das Dasein'. This noun is meant to designate a mode of being ('Seinsweise') not an individual (or a group of individual entities) defined by essences (or essential properties). The task of fundamental ontology is to spell out the basic structure of the peculiar mode of being that is called 'Dasein' and to get rid as well of the traditional substance ontology that Heidegger regards as highly problematic as of the theories of subjectivity that dominated western philosophy.

Understanding is one of the fundamental categories Heidegger presents in characterizing the mode of being called 'Dasein'. In the existential and hermeneutical perspective understanding is a universalized concept applicable even on a pre-linguistic, pre-conceptual level. 'Dasein' means to stand always already in an irrevocable and indissoluble relation to sense and meaning. Even on the most elementary level understanding is involved: Hearing a cry is not a passive reception of the given, but a grasp of the given as something meaningful. Understanding thus is present in all forms of human experience. The universalized hermeneutic notion of understanding then is not bivalent. The distinction of adequate/ successful versus inadequate/unsuccessful understanding is not to be made on the basic level since misunderstanding too is derivative from the basic, ontological understanding. In order to misunderstand a sign or a message you have at least to grasp sense or meaning even if it is in a mistaken way. Understanding, for Gadamer, is within the weave of everyday life. On the level of the universalized hermeneutical understanding, there can be no complete lack of understanding, as it inheres in the existence of human beings. Cases of the absence of understanding ("I don't understand at all what is going on there") are less problematic than cases of misunderstanding. The person who does not understand at all 
can be aware of the fact that she needs to look for the adequate meaning, whereas someone who falls prey to a misunderstanding simply ignores the fact that he does not possess an adequate understanding.

Gadamer develops Heidegger's ideas in a new direction by stressing the fact that understanding is conditioned and mediated by language, historicality, and tradition. Roughly speaking, one could call Wahrheit und Methode a modification of central tenets in Heidegger's fundamental ontology, a modification that extends the focus on historial and cultural processes, regarded as conditions of interpretation and understanding.

Interpretation is the ascription of meaning to texts, signs, and objects. As intentional and rule-governed activities interpretations can ascribe the meaning in relation to some interpretational schema, but sometimes they may go wrong. Therefore the major task of traditional hermeneutics was to answer questions about the different forms of interpretation and the methods these specific forms of interpretation could use. Heidegger and Gadamer rejected this way of proceeding. They claimed, firstly, understanding to be elementary processes that are in function on all levels of thought, language, and action. And the claimed, secondly, that there is no possibility to guarantee interpretative success by following methods of interpretation. To say this is not to ignore the fact that it may be important to observe specific methodological rules that can be necessary in order to reach a sound interpretation. But the fulfillment of such necessary conditions is not to be taken in itself as sufficient for sound interpretation. ${ }^{7}$ If one does not want to get stuck with polemical invectives against this methodological nonchalance of Gadamer one has to take into account the motives for his disinterestedness. He wants to make evident that methodological thought depends on a highly complex structure of conditions. He wants his readers to see that understanding is not only secured by conscious and reflective argumentation and interpretation but that it is conditioned by language, life-form and history. Understanding is not primarily a controlled activity but an event.

Undoubtedly Gadamer is not very clear on this point. His universalization of understanding is accompanied by a dismissive attitude towards methodology and epistemology in general. A concise diagnosis is given by P. Ricœur: "[Heidegger] a voulu que nous subordonnions la connaissance historique à la compréhension ontologique, comme une forme dérivée d'une forme originaire. Mais il ne nous donne aucun moyen de montrer en quel sens la compréhension proprement historique est dérivée de cette compréhension originaire." (Ricoeur, 1969, p. 14). 


\section{II.2. A comeback of Aristotle's 'phronēsis'}

Wahrheit und Methode uses Aristotle's 'phronēsis' as a model for the kind of knowledge that is relevant in hermeneutic experience and in the humanities. Gadamer is not primarily interested in revalidating Aristotle's ethical thinking. His strategy is to pinpoint the specification of 'phronēsis', to contrast practical and theoretical knowledge, and to explain how the humanities, the interpretive disciplines altogether, are to be comprehended in analogy with practical knowledge. The essential contention then is that knowledge in the humanities cannot be identified with theoretical knowledge. Interpretative knowledge is not knowledge at distance, it is intrinsically contextual und personal. Gadamer thinks the humanities to be on the wrong track as long as they understand themselves exclusively in a scientistic way, i.e. as object-directed research. Object-directed research obeys the logic of theoretical knowledge. Since the humanities and all other disciplines proceeding by way of interpretation can be analyzed only partially in terms of theoretical knowledge, other forms of knowledge have to be recognized. Gadamer claims that it is practical knowledge that is involved in the interpretative disciplines. ${ }^{8}$ The interpreter does not proceed as the scientist by strict deduction or induction in order to fix the meaning of the text. Interpretation is an intellectual activity that is analogous to the deliberative process of practical reason. How can Gadamer justify his thesis? - Like the practical knowledge of the prudent person who determines her choice in a concrete situation the knowledge of the interpreter determines the meaning of the text in a concrete context.

Following Gadamer an interpreter stands in a special relation to tradition. Adherence/affiliation ('Zugehörigkeit') to a tradition is a constitutive aspect of Gadamer's model of interpretation. This means primarily that the interpreter is herself member of a language community, a culture with its specific conceptual resources. She can try to reflect on the conditions that enable her to perform the interpretative acts and impinge upon her, but she will never be in a position to have an transparent and distinct grasp on the whole situation by objectifying her own conceptual framework and contrast it with the conceptual framework of the text. Of course, it is necessary for every serious interpretation to analyze the structure and semantics of the text. Gadamer certainly would not deny that the reconstruction of textual meaning is a methodologically guided activity and not to be conflated with wild projections of the reader's own ideas on the text. But he insists that interpretation is conditioned by presuppositions that are neither reflectively controllable nor otherwise eliminable. Suppose an interpreter is

8 In 1930 Gadamer uses the term 'praktisches Wissen' (practical knowledge), in Wahrheit und Methode (1960) mostly 'sittliches Wissen' (ethical knowledge). There is no explanation given in Gadamer's text itself for this change. 
reading a text from the $18^{\text {th }}$ century arguing for the abolition of slave trade. Probably, her comprehension of the text will start with the normative judgment of contemporary western culture that slavery is inacceptable and a violation of human rights. This is what Gadamer calls a prejudice concerning the matter of the text. And against all objectivistic conceptions of interpretation Gadamer argues that such prejudices are legitimate. You cannot start with interpretation without presupposing anything. We have to begin with our language and our concepts even if we expect in the case of historical interpretation that we will probably be facing problems and misunderstandings and, consequently, will have to widen our conceptual repertoire by considering other differentiations and normative distinctions than those we are familiar with in our own everyday life. The goal of interpretation is the integration of the text into the world of the reader. This integration cannot be achieved if the interpreter tries to abstract from his own context. She has to accomplish a mediation, a fusion of the horizon of the text and of her own horizon. The hermeneutical understanding that is the result of good interpretations is not acquisition of information concerning an object but integration of textual meaning into the conceptual and normative framework of the reader.

Philosophical hermeneutics then proclaims contextualism and pluralism of interpretation. That is: only in very technical or trivial cases is there one single adequate interpretation. Interpretations in formal languages or calculus systems are the paradigm cases. But under standard circumstances, there is no strict synonymy of meaning. Therefore there is no systematic, unambiguous, unequivocal and well-defined meaning. Does all this amount to sheer chaos or to deconstruction of the very concept of meaning? - Not at all. Think of translation. In general, it is impossible to say there would be only one single translation of a text. But that is not to say that there are no wrong translations. Elimination of wrong interpretations is of paramount importance for a pluralistic conception of understanding and interpretation. Interpretation may well require some leeway, due to the complex nature of signification. But that has nothing to do with arbitrariness or sloppiness. So, interpretation in the social sciences as everywhere else is bound to rest an exercise of concentration, patience, and precision.

\section{Polity, 'phronēsis', and Political Science}

In various papers the late Gadamer reiterates his Aristotelian insights and considerably reinforces his references to the preeminent and indispensable function of practical knowledge. ${ }^{9}$ He is disquieted by a forceful tendency to assimi-

$9 \quad$ Cf. especially Gadamer, 1986f, 1986g, 1986h, 1986 i. 
late praxis to theory, to conceive of the lifeworld nearly exclusively as a field for the application of technologies and new scientific results. Alarmism and apocalyptic exaggerations are no temptations to Gadamer's temperament. He serenely formulates reservations about a monopolistic conception of scientific truth and technological reason. Science gets into difficulty when it is regarded as the religion of modern culture. The use and application of science to praxis is in itself not a scientific act, but presupposes a practical decision. The idea that practical orientation can be given by experts seems to be a category mistake. Experts are able to communicate theoretical and technical knowledge. This is factual knowledge. But such factual, theoretical or technological knowledge cannot replace practical knowledge. Practical deliberation is primarily deliberation on normative or evaluative questions. Answering such questions implies a decision on normative or evaluative issues. Of course, an expert can give information used in deliberations about goals of action and norms for behavior. Gadamer by no means ignores the necessity of modern societies to acquire scientific and technological knowledge. But he does not accept the idea that one can replace practical deliberation by scientific explanation or technological information. Science has changed the world. Rationalization of society and domination of nature are to a considerable extent realized by means of scientific knowledge. But modern societies are carried away by this success story in a dangerous way if they forget the responsibility and the deliberative potential of the citizens. Deliberation is a dialogical practice. The emphasis on dialogue as medium of practical reasoning is a modification of Aristotle's concept of practical knowledge by Gadamer. It is the dialogical encounter that is a necessary counterpart to the monological reasoning of theory and technology. Information is not to be mistaken for practical knowledge or reason (Gadamer, 1986g, pp. 218-219).

The late Gadamer was convinced that Aristotle's analysis of the concept of practical knowledge was still valid today. Practical knowledge is the capacity to render a judgment appropriate to a given, concrete situation. Aristotelian 'phronēsis', according to Gadamer, is very much like the faculty of judgment. Translated into a concrete political situation, practical knowledge is what we use to answer the question "What is here and now the best thing to do for me and my fellow citizens?".

Practical knowledge is not theoretical knowledge. It rests on experience, acuteness of perception and judgment. Neither individuals nor collectives can expect a scientific answer to the question "Which is here and now the right way to make a good life?". The very concept of praxis is deformed if theoretical rationality is the sole authority accepted in the domain. Theoretical rationality is anonymous and monological. Mathematical proof, the paradigm of purely theoretical thought, is valid irrespective of the speaker. These conditions don't obtain in the area of practical action, where individuals depend not only on the exchange of knowledge and information but also on discussions of evaluative and 
normative judgments which can entirely change the meaning of the knowledge exchanged. Dialogue and discussion give place to a plurality of verdicts on evaluative and normative issues. Controversy and argument help to sharpen the individual's thinking thanks to the perception of inconsistencies and contradictions. Practical knowledge can never give legitimation to a decision by apodictic proof. To the contrary, practical knowledge is unable to preclude uncertainty and unpredictability. There are questions of relevance, for example, that have to be taken into account; there are the different existential situations of the participants, who can only partially collaborate one with another. The decision is always a decision under risk of failure. Yet far from being an objection against such ways of decision-making, it is in fact the primitive condition for it. If political science does not respect the open, a-systematic structure of the political, if it does not acknowledge the plurality and the essential unpredictability of praxis, it will quickly deform the phenomena by treating them solely in terms of theoretical rationality.

\section{References}

Aubenque, P. (1986). La prudence chez Aristote. Paris: Presses Universitaires de France. Dutt, C. (ed.). (1993). Hans-Georg Gadamer im Gespräch. Heidelberg: Winter.

Gadamer, H.-G. (1922). Das Wesen der Lust nach den platonischen Dialogen.

Gadamer, H.-G. (1986a). "Aristoteles und die imperativische Ethik". In: idem. Gesammelte Werke. Vol. 7. Tübingen: Mohr Siebeck, pp. 381-395.

Gadamer, H.-G. (1986b.) "Der hermeneutische Vorrang der Frage". In: idem. Gesammelte Werke. Vol. 1. Tübingen: Mohr Siebeck, pp. 346-384.

Gadamer, H.-G. (1986c). "Die Erhebung der Geschichtlichkeit des Verstehens zum hermeneutischen Prinzip". In: idem. Gesammelte Werke. Vol. 1. Tübingen: Mohr Siebeck, pp. 270-312.

Gadamer, H.-G. (1986d). "Die Universalität des hermeneutischen Problems (1967)”. In: idem. Gesammelte Werke. Vol. 2. Tübingen: Mohr Siebeck, pp. 219-232.

Gadamer, H.-G. (1986e). Gesammelte Werke. Vol. 5. Tübingen: Mohr Siebeck.

Gadamer, H.-G. (1986f). Gesammelte Werke. Vol. 2. Tübingen: Mohr Siebeck.

Gadamer, H.-G. (1986g). Gesammelte Werke. Vol. 4. Tübingen: Mohr Siebeck.

Gadamer, H.-G. (1986h). Gesammelte Werke. Vol. 7. Tübingen: Mohr Siebeck.

Gadamer, H.-G. (1986i). Gesammelte Werke. Vol. 10. Tübingen: Mohr Siebeck.

Gadamer, H.-G. (1986j). "Paul Friedländer”. In: idem. Gesammelte Werke. Vol. 10. Tübingen: Mohr Siebeck, pp. 403-405.

Gadamer, H.-G. (1986k). “Paul Natorp”. In: idem. Gesammelte Werke. Vol. 10. Tübingen: Mohr Siebeck, pp. 375-380.

Gadamer, H.-G. (19861). "Platos dialektische Ethik (1931)”. In: idem. Gesammelte Werke. Vol. 5. Tübingen: Mohr Siebeck, pp. 3-163.

Gadamer, H.-G. (1986m). "Praktisches Wissen (1930)". In: idem. Gesammelte Werke. Vol. 5. Tübingen: Mohr Siebeck, pp. 230-248. 
Gadamer, H.-G. (1986n). “Replik zu Hermeneutik und Ideologiekritik (1971)”. In: idem. Gesammelte Werke. Vol. 2. Tübingen: Mohr Siebeck, pp. 251-275.

Gadamer, H.-G. (1986o). "Rhetorik, Hermeneutik und Ideologiekritik. Metakritische Erörterungen zu Wahrheit und Methode (1967)”. In: idem. Gesammelte Werke. Vol. 2. Tübingen: Mohr Siebeck, pp. 232-250.

Gadamer, H.-G. (1986p). "Wahrheit und Methode - Grundzüge einer philosophischen Hermeneutik (1960)”. In: idem. Gesammelte Werke. Vol. 1. Tübingen: Mohr Siebeck.

Grondin, J. (1991). Einführung in die philosophische Hermeneutik. Darmstadt: Wissenschaftliche Buchgesellschaft.

Natorp, P. (1903). Platos Ideenlehre, eine Einführung in den Idealismus. Leipzig: Durrschen Buchhandlung.

Ricoeur, P. (1969). "Existence et herméneutique”. In: idem. Le conflit des interprétations: Essais d'herméneutique. Paris: Seuil, pp. 7-28.

Schofield, M. (2006). “Aristotle’s Political Ethics”. In: R. Kraut (ed.). The Blackwell Guide to Aristotle's Nicomachean Ethics. Oxford: Blackwell Publishing, pp. 305-322.

Teichert, D. (2004). “Zirkel, hermeneutischer”. In: J. Ritter, K. Gründer, G. Gabriel (eds.). Historisches Wörterbuch der Philosophie. Basel: Schwabe.

Turk, H. (1982). "Wahrheit oder Methode? H.-G. Gadamers, Grundzüge einer philosophischen Hermeneutik". In: H. Birus (ed.). Hermeneutische Positionen: Schleiermacher, Dilthey, Heidegger, Gadamer. Göttingen: Vandenhoeck \& Ruprecht.

Wolf, U. (2002). Aristoteles' 'Nikomachische Ethik'. Darmstadt: Wissenschaftliche Buchgesellschaft.

Zedler, J.H. (1961). "Platonische Philosophie”. In: Grosses vollständiges Universal-Lexikon. Graz: Akademische Druck- und Verlangsanstalt. 